\title{
URGENSI PEMERIKSAAN PSIKIS PRA-NIKAH (Studi Pandangan Kepala KUA dan Psikolog Kota Malang)
}

\author{
Ika Kurnia Fitriani \\ Pengadilan Agama Nunukan \\ ikakurniafitriani@gmail.com
}

\begin{abstract}
Some of Muslim countries giving more attention to the psychological check of pre-marriage for both spouse candidates, it means to prevent any domestic violence problem that possibly happening because of psychological matter in the future. This research intended to know the perspective of Head of KUA and Psychologist in Malang district toward the psychological check-up and its urgency for marriage candidates. As one of field research, this research use qualitative approach. The data analyzed in three general steps; data reduction, data presentation, and conclusion. Moreover, the data validated by triangulation method, which comparing the interview data with secondary data, and theory. Finally, the result states that the Head of KUA and Psychologist of Malang district agreed in provisioning the pre-marriage psychological check-up, but due to effectiveness, it should regulated and socialized. In addition, this pre-marriage psychological check-up is not contrary with the concept of maqashid al-syariah and sadz al-dzari'ah in Islamic Law.

Beberapa negara muslim memberikan perhatian terhadap pemeriksaan psikis pra-nikah bagi calon mempelai, sebagai upaya menanggulangi masalah rumah tangga akibat gangguan kejiwaan di masa yang akan datang. Penelitian ini bertujuan menggali informasi dari Kepala KUA dan Psikolog di Kota Malang tentang pemeriksaan psikis pra-nikah dan urgensinya bagi calon mempelai. Penelitian ini termasuk dalam penelitian lapangan (field reasearch), dengan menggunakan pendekatan kualitatif. Alanisis data dilakukan melalui tiga tahapan yaitu reduksi data, penyajian data, dan menarik kesimpulan. Pengecekan keabsahan data menggunakan triangulasi sumber yang membandingkan hasil wawancara dengan data sekunder, dan triangulasi teori. Hasil dari penelitian ini menunjukkan bahwa Kepala KUA dan Psikolog di kota Malang menyetujui diadakan pemeriksaan psikis pranikah akan tetapi harus ada aturan hukumnya dan dilakukan sosialisasi agar program menjadi efektif. Selain itu, pemeriksaan psikis pra-nikah tidak bertentangan dengan konsep maqashid al-syari'ah dan konsep sadz al-dzari'ah dalam hukum Islam.
\end{abstract}

Kata Kunci: Pemeriksaan Psikis, Pra-Nikah, KDRT

Perkawinan merupakan ikatan lahir batin antara laki-laki dan perempuan yang dilegalkan oleh agama dan negara. Sebelum membangun kehidupan rumah tangga, kedua calon mempelai sangat dianjurkan telah memiliki kedewasaan dan kesiapan, baik secara fisik, psikologis, maupun ekonomi guna mencapai tujuan perkawinan yaitu terwujudnya keluarga yang kekal dan harmonis. ${ }^{1}$ Upaya mewujudkan kondisi ideal ini tidak selalu berhasil, tidak sedikit pasangan suami-istri yang mengakhiri

${ }^{1}$ Ali Murtadho, Konseling Perkawinan Perspektif Agama-Agama (Semarang: Walisongo Press, 2009), h. vivii 
rumah tangganya dengan perceraian. Salah satu faktor penyebabnya adalah kekerasan dalam rumah tangga, baik secara fisik, psikis, seksual maupun ekonomi.

Data Komnas Perempuan menunjukkan bahwa kekerasan di wilayah domestik masih saja terjadi setiap tahunnya. Pada tahun 2010, terjadi 105.103 kasus kekerasan terhadap perempuan dan 101.128 kasus (96\%) di antaranya merupakan kekerasan dalam rumah tangga. ${ }^{2}$ Pada tahun 2011 terjadi 119.107 kasus kekerasan dan $95,61 \%$ atau 113.878 kasus adalah KDRT. ${ }^{3}$ Pada tahun 2012 telah terjadi 216.156 kasus kekerasan dengan 8.315 kasus (66\%) terjadi di ranah privat. ${ }^{4}$ Sedangkan pada tahun 2013 terjadi 279.688 kasus kekerasan dan 11.719 kasus $(71 \%)$ terjadi di wilayah domestik. ${ }^{5}$

\section{Grafik Kekerasan Terhadap Perempuan}

Tahun 2001-2013

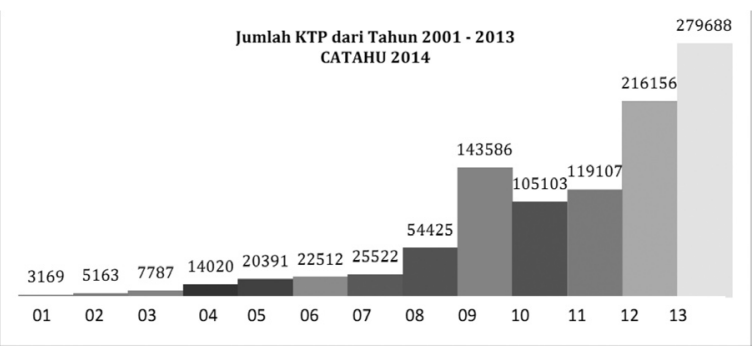

Data Komnas Perempuan tahun 2011 menunjukkan bahwa kekerasan terhadap perempuan banyak terjadi di wilayah Jawa Tengah dan Jawa Timur: 25.628 dan 24.555 korban. Jawa Barat dan DKI Jakarta menyusul: 17.720 dan 11.286 korban. ${ }^{6}$ Pada tahun 2012, terdapat

${ }^{2}$ Komnas Perempuan, Teror dan Kekerasan Terhadap Perempuan: Hilangnya Kendali Negara Catatan KTP Tahun 2010 (Jakarta: Komnas Perempuan,2011), h. 11

${ }^{3}$ Komnas Perempuan, Stagnansi Sistem Hukum: Menggantung Asa Perempuan Korban Catatan KTP Tahun 2011, (Jakarta: Komnas Perempuan,2012), h. 4

${ }^{4}$ Komnas Perempuan, Korban Berjuang, Publik Bertindak: Mendobrak Stagnansi Sistem Hukum Catatan KTP Tahun 2012, (Jakarta: Komnas Perempuan, 2013), h. 7

${ }^{5}$ Komnas Perempuan, Kegentingan Kekerasan Seksual Lemahnya Upaya Penanganan Negara Catatan Kekerasan Terhadap Perempuan Tahun 2013, (Jakarta: Komnas Perempuan, 2013), h. 15

${ }^{6}$ Komnas Perempuan, Stagnansi, h. 10
5 provinsi dengan jumlah kasus kekerasan paling tinggi antara lain: DKI Jakarta (1.699 kasus), Jawa Timur (1.593 kasus), Jawa Barat (1.352 kasus), Jawa Tengah (1.052 kasus), dan Sumatera Barat (902). ${ }^{7}$ Dan pada tahun 2013, ada 6 provinsi dengan jumlah kasus lebih dari 1000, yaitu: DKI Jakarta (2.881), Sumut (2.023), Jabar (1.846), Jatim (1.539), Jateng (1.495), dan Lampung (1.326). ${ }^{8}$ Berdasarkan tiga data di atas, di wilayah Jawa Timur sangat rawan terjadi kekerasan terhadap perempuan.

Sementara itu data statistik dan analisis gender, anak, dan perempuan propinsi Jawa Timur pada tahun 2009 menyebutkan bahwa Kota Malang menduduki peringkat ke- 5 kasus kekerasan terhadap perempuan (kekerasan dalam rumah tangga) terbesar di propinsi Jawa Timur yaitu pada tahun 2005 berjumlah 33 kasus, tahun 2006 mengalami kenaikan berjumlah 60 kasus, tahun 2007 juga mengalami kenaikan sebanyak 78 kasus, dan pada tahun 2008 kasus kekerasan dalam rumah tangga mengalami penurunan yaitu berjumlah 43 kasus. ${ }^{9}$ Catatan Pengadilan Agama Kota Malang juga menunjukkan bahwa perkara perceraian diputus karena kekerasan dalam rumah tangga, mengalami peningkatan. Pada tahun 2009, Pengadilan Kota Malang memutus 188 kasus perceraian karena KDRT, tahun 2010 meningkat menjadi 192 kasus, kemudian terhadi peningkatan signifikan pada tahun 2011 yaitu 330 kasus dan tahun 2012 terdapat 425 kasus. $^{10}$

Tindak kekerasan dalam rumah tangga disebabkan oleh berbagai faktor. Lamber Missa menyatakan bahwa faktor penyebab KDRT adalah cemburu, ekonomi, dan minuman keras. ${ }^{11}$ Sedangkan hasil penelitian Moerti

${ }^{7}$ Komnas Perempuan, Korban Berjuang..., h. 12

${ }^{8}$ Komnas Perempuan, Kegentingan..., h. 23

${ }^{9}$ Kementerian Negara Pemberdayaan Perempuan Republik Indonesia dan Badan Pemberdayaan Perempuan dan Keluarga Berencana Provinsi Jawa Timur, Statistik dan Analisis: Gender, Anak, dan Perempuan Provinsi Jawa Timur Tahun 2009 (Surabaya, 2009), h. 62

${ }^{10}$ Penyebab Perceraian tahun 2009-2012. www.pamalangkota.go.id, diakses tanggal 20 Januari 2013.

${ }^{11}$ Lamber Missa, Studi Kriminologi Penyelesaian 
Hadiati menunjukkan bahwa KDRT disebabkan masalah anak, cemburu, problem ekonomi dan campur tangan keluarga. ${ }^{12}$ Menurut Dadang Hawari beberapa penyebab KDRT masuk dalam kategori gangguan kejiwaan. ${ }^{13}$ Meskipun demikian, pemeriksaan kesehatan bagi calon pengantin masih terfokus pada kesehatan fisik an sich. ${ }^{14}$ Sedangkan UndangUndang Nomor 36 Tahun 2009 tentang Kesehatan mengamanatkan bahwa keadaan sehat meliputi sehat fisik, mental, spritual maupun sosial. ${ }^{15}$ Berdasarkan berbagai persoalan di atas penelitian ini berupaya menggali informasi Kepala KUA dan Psikolog di Kota Malang tentang pemeriksaan psikis pra-nikah dan urgensinya dalam mencegah tindak kekerasan dalam rumah tangga

\section{Tinjauan Pustaka}

\section{Definisi Kesehatan Mental}

Zakiah Daradjat mendefinisikan kesehatan mental sebagai suatu kondisi terwujudnya keserasian yang sungguh-sungguh antara fungsifungsi kejiwaan dan terciptanya kemampuan penyesuaian diri manusia dengan diri sendiri, dan terhadap sesamanya dengan berlandaskan keimanan dan ketakwaan, serta dengan tujuan untuk mencapai hidup bermakna dan bahagia dunia akhirat. ${ }^{16}$ Definisi di atas mengandung empat indikator antara lain: Pertama, adanya wujud integritas kepribadian seseorang yang tampak dalam kemampuannya menghindar dari segala gangguan dan penyakit kejiwaan. Kedua, adanya wujud integritas kepribadian seseorang yang tampak pada kemampuan menyesuaikan

Kekerasan Dalam Rumah Tangga Di Wilayah Kota Kupang Propinsi Nusa Tenggara Timur (Semarang: Fakultas Hukum Univ. Diponegoro, 2010)

${ }^{12}$ Moerti Hidayati Soeroso, Kekerasan dalam Rumah Tangga dalam perspektif yuridis-viktimologis (Jakarta: Sinar Grafika, 2010), h. 124

${ }^{13}$ Dadang Hawari, Penyiksaan Fisik dan Mental dalam Rumah Tangga (Domestic Violence) (Jakarta: Balai Penerbit Fakultas Kedokteran Universitas Indonesia, 2009), h. 28-35

${ }^{14}$ Instruksi Depag dan Depkes No. 1 tahun 1989 tentang Pemeriksaan Kesehatan Pranikah.

${ }^{15}$ Undang-Undang Nomor 36 Tahun 2009 tentang Kesehatan LN. Tahun 2009 No, 144

${ }^{16}$ Ikrom AM, Persinggungan Antara Psikopatologi dan Kesehatan Mental Sufistik (Semarang: Walisongo Press, 2009), h. 6 diri, baik terhadap diri sendiri (حبل من النفس) (حبل), sesama manusia (حبل من الناس), lingkungan (حن من (حبل (حبل), (من العاله), dan terhadap Sang Khaliq (حبل من (حبل (حن الله). Ketiga, adanya wujud integritas kepribadian seseorang yang tampak pada kemampuan mengendalikan diri. Keempat, wujud integritas kepribadian seseorang yang tampak pada keserasian antara fungsi kejiwaan, dengan cirri-ciri adanya keserasian antara pikiran, perasaan, ucapan, dan perilaku. ${ }^{17}$

\section{Macam-Macam Gangguan Kejiwaan}

Menurut Diagnostic Statistical Manual of Mental Disorders, sebagaimana dikutip dari Hawari menyatakan bahwasanya terdapat 13 jenis gangguan kepribadian (Personality Disorders), antara lain: ${ }^{18}(1)$ Gangguan Kepribadian Psikopatik (Psychopatic/Antisosial Personality Disorders) yaitu pola gangguan kepribadian yang didominasi oleh ketidakpedulian dan pelanggaran terhadap tata tertib, norma, etika dan hukum yang berlaku; (2) Gangguan Kepribadian Paranoid (Paranoid Personality Disorders) yaitu pola kepribadian yang didominasi oleh ketidak-percayaan dan kecurigaan terhadap orang lain disertai rasa dengki. Menurut Maramis, ganguan kepribadian paranoid ini ditandai dengan sifat curiga yang berlebih terhadap pasangannya maupun orang lain dan kadang juga disertai dengan sifat agresif, ia juga melihat orang lain selalu bersifat aggressor kepadanya, ia harus mempertahankan dirinya terhadap ancaman dari luar; (3) Gangguan Kepribadian Skizoid (Schizoid Personality Disorders) yaitu pola kepribadian yang didominasi oleh pemisahan diri dari pergaulan sosial dan menyempitnya ekspresi emosional (dingin) ${ }^{19}$; (4) Gangguan Kepribadian

\footnotetext{
${ }^{17}$ Ikrom AM, Persinggungan.., 6

${ }^{18}$ Dadang Hawari, Penyiksaan Fisik dan Mental dalam Rumah Tangga (Domestic Violence) (Jakarta: Balai Penerbit FKUI, 2009), h. 32-35

${ }^{19}$ Menurut Baihaqi, orang yang mengalami gangguan kepribadian ini memiliki sifat-sifat kepribadian seperti pemalu, perasa, pendiam, suka menyendiri, menghindari kontak sosial dengan orang lain. Lihat, MIF Baihaqi, dkk, Psikiatri Konsep Dasar dan Gangguan-Gangguan (Bandung: Refika Aditama, 2007), h. 134; Marawis menjelaskan, orang yang memiliki gangguan kepribadian ini sering menunjukkan respons yang terbatas terhadap isyarat atau rangsangan sosial, ia kurang mampu mengekspresikan
} 
Skizotipal (Schizotipan Personality Disorders) yaitu pola kepribadian yang didominasi oleh rasa tidak nyaman dalam hubungan dengan orang lain, penyimpangan pola pikir (cognitive) atau persepsi dan perilaku yang eksentrik (aneh). ${ }^{20}$; (5) Gangguan Kepribadian Ambang (Borderline Personality Disorders) yaitu pola kepribadian yang didominasi oleh ketidak-stabilan dalam hubungan pergaulan sosial, citra diri (selfimage), alam perasaan (affects) dan tindakan yang tiada terduga serta menyolok (marked impulsivity); (6) Gangguan Kepribadian Histerik (Histrionic Personality Disorders) yaitu Ciri utama kepribadian ini adalah sombong, egosentrik, tidak stabil emosinya, suka menarik perhatian dengan efek yang labil, sering berdusta dan menunjukkan pseudologika fantastika atau menceritakan sesuatu secara luas, terperinci dan kelihatan masuk akal, padahal tanpa dasar fakta atau data. Baihaqi menambahkan bahwa orang yang mengalami gangguan histerik dalam hal seks biasanya terlihat provokatifagresif, menggairahkan, serta menggoda, padahal mungkin dia sebenarnya frigid. ${ }^{21} ;(7)$ Gangguan Kepribadian Narsisistik (Narsisistic Personality Disorders) yaitu pola kepribadian yang didominasi oleh perasaan dirinya hebat, senang dipuji dan dikagumi serta ada rasa empati (tidak punya perasaan); (8) Gangguan Kepribadian Menghindar (Avoidant Personality Disorders) yang didominasi oleh hambatan sosial, perasaan tidak percaya diri dan sangat sensitive terhadap hal-hal yang negative. Suparno dan

kehangatan, kelembutan atau kemarahan terhadap orang lain, ia juga kurang kurang tertarik terhadap pengalaman sexual dengan orang lain. Ia berpreokupasi dengan fantasi dan berintrospeksi berlebihan, ia tidak peduli, baik terhadap pujian maupun terhadap kecaman, tidak mempunyai teman akrab, sangat tidak sensitive terhadap norma dan kebiasaan sosial yang berlaku, selalu memilih aktivitas yang dilakukan sendiri. Lihat, Willy F. Maramis dan Albert A. Maramis, Catatan Ilmu Kedokteran Jiwa (Surabaya: Airlangga University Press, 2009), h. 335; Menurut Ardani, gangguan kepribadian schizoid umumnya terjadi pada 7,5 populasi dan perbandingan antara laki-laki dan perempuan jumlahnya tidak pasti, akan tetapi diperkirakan perbandingannya sekitar 2:1 (laki-laki: perempuan). Gangguan ini biasanya muncul pada awal masa kanak-kanak dan berlangsung dalam waktu yang lama. Lihat, Tristiadi Ardi Ardani, Psikiatri Islam (Malang: UIN-Malang Press, 2008), h. 224

${ }^{20}$ Dadang Hawari, Penyiksaan Fisik..., h. 89

${ }^{21}$ MIF Baihaqi, dkk, Psikiatri..., h. 135
Sudjiwanati menegaskan, bahwasanya seseorang yang mengalami gangguan kepribadian jenis menghindar memiliki cirri-ciri antara lain: perasaan tegang dan takut yang menetap dan pervasive, merasa dirinya tidak mampu, tidak menarik atau lebih rendah dari orang lain, preukopasi yang berlebihan terhadap kritik dan penolakan dalam situasi social, keengganan untuk terlibat dengan orang kecuali merasa yakin akan disukai; (9) Gangguan Kepribadian Astenik (Dependent Personality Disorders) yaitu pola kepribadian yang didominasi oleh ketidakmampuan untuk berdiri sendiri, ketergantungan terhadap orang lain dan keinginan untuk selalu dilayani; (10) Gangguan Kepribadian Anankastik (Obsessive Compulsive Personality Disorders) yaitu pola kepribadian yang didominasi oleh pikiran yang terpaku (preoccupation) terhadap kebiasaan sehari-hari, control diri yang kuat dan serba ingin sempurna (perfectionism); (11) Gangguan Kepribadian Siklotimik (Affective Personality Disorders) yaitu pola kepribadian yang didominasi gangguan alam perasaan (affective) yang ditandai oleh gejala gembira berlebihan dan sedih berlebihan. (12) Gangguan Kepribadian Eksplosif (Explossive Personality Disorders) yaitu pola kepribadian yang didominasi oleh hilangnya pengendalian emosi (agresif) yang mengakibatkan tindakan kekerasan dan kerusakan harta benda; (13) Gangguan Kepribadian Pasif-Agresif (Passive-Aggressive Personality Disorders) yaitu pola kepribadian yang didominasi oleh perilaku yang tidak wajar terhadap pekerjaan maupun pergaulan sosial, misalnya berlambat-lambat, mengulur waktu dengan alas an "lupa".

Gangguan-gangguan kepribadian tersebut diatas dapat diukur atau diketahui dengan menggunakan alat ukur (skala) yang dinamakan MMPI (Minnesota Multiphasic Personality Inventory). ${ }^{22}$ MMPI adalah salah satu bentuk tes psikologik yang disusun sedemikian rupa sehingga merupakan instrument yang secara akurat dapat memberikan gambaran dari

${ }^{22}$ Dadang Hawari, Psikometri Alat Ukur (Skala) Kesehatan Jiwa Jakarta: Balai Penerbit Fakultas Kedokteran Universitas Indonesia, 2009), h. 7 
dimensi-dimensi kepribadian tertentu..$^{23}$ Menurut Hawari, dari sekian banyaknya gangguan kepribadian tersebut diatas, yang seringkali mengakibatkan terjadinya kekerasan dalam rumah tangga (KDRT) antara lain gangguan kepribadian Antisosial (Psikopat), Paranoid dan Eksplosif. ${ }^{24}$ Selain itu Hawari juga menjelaskan bahwasannya selain dari gangguan kepribadian kekerasan dalam rumah tangga juga dapat disebabkan adanya gangguan jiwa, diantara gangguan jiwa yang sering mengakibatkan terjadinya kekerasan dalam rumah tangga adalah Skizofrenia. ${ }^{25}$

\section{Faktor Penyebab Gangguan Kejiwaan}

Gangguan psikis tidak begitu saja terjadi, akan tetapi ada beberapa yang melatarbelakanginya antara lain faktor fisik (jasmaniyah), faktor psikis dan struktur kepribadian, dan faktor sosial yang kesemuanya itu menurut Kartini Kartono disebut faktor multi-kasusal. ${ }^{26}$ Faktor organik biasanya muncul akibat penyakitpenyakit jasmaniah, terutama penyakit yang tidak dapat disembuhkan, yang mengakibatkan kerusakan pada system syaraf otak yang pasti mengakibatkan munculnya gangguangangguan seperti: perubahan karakter dengan gejala amnetis, anomali-anomali (abnormalitas tingkah laku), proses dementia dan hilangnya atau menurunnya kesadaran. Selain itu ada juga penyakit infeksi dan pertukaran zat yang dibarengi dengan beberapa faktor fisik dan mengakibatkan gejala penyakit berupa: delier (lepas, terurai, menjadi gila, panas hati, dipenuhi kecemasan dan kegelisahan, kadang-kadang juga mengigau dan meracau), kaburnya kesadaran dan sindrom hyperesthetis-emosional. ${ }^{27}$

Faktor psikis dan struktur kepribadian sangatlah berkesinambungan. Gangguangangguan psikis dalam wujud neurosa, psikosa, dan psikopat merupakan perlakuan

${ }^{23}$ Dadang Hawari, Psikometri..., h. 58

${ }^{24}$ Dadang Hawari, Penyiksaan Fisik..., h 35

${ }^{25}$ Dadang Hawari, Penyiksaan Fisik..., h.75

${ }^{26}$ Kartini Kartono, Patologi Sosial 3: GangguanGangguan Kejiwaan (Jakarta: PT RajaGrafindo Persada, 2012), h. 27

${ }^{27}$ Kartini Kartono, Patologi..., h.28 yang cenderung patologis dari tempramentempramen. Dalam diri seseorang pastilah terdapat kepribadian yang berbeda dengan kepribadian orang lain. Menurut Kartini Kartono, pada kepribadian tipe amorf dan apatikus hampir tidak pernah muncul gejala gangguan psikis yang khas. Sebaliknya tipe nerveus biasanya cenderung histeris, neurasthenis dan hipokondris karena sifat tempramen-tempramennya dan menjadi patologis. Tipe sentimentil biasanya sering muncul gejala-gejala depresi, melankoli dan psikhasteni. Tipe sanguinikus cenderung banyak menampilkan gejala-gejala mania, gembira dan lepas hati yang sifatnya patologis. Sedangkan tipe gepassioneerd sering mengalami gangguan paranoia. ${ }^{28}$ Menurut Kartini Kartono, faktor warisan psikis itu sifatnya bisa genetis, sekaligus juga psikis. Dikatakan genetis karena merupakan konstitusi psikis yang diwarisi dan erat kaitannya dengan konstitusi fisik, jadi terdapat faktor keturunan. Sedangkan sifat psikis berawal dari pengalaman-pengalaman yang diderita individu dan menjadi peristiwa psikotraumatis yang memunculkan dekompensasi psikotis pada individu, dengan predisposisi psikis yang lemah dan labil. ${ }^{29}$

Selain dari pada faktor organis dan psikis ada juga faktor sosial yang juga menjadi penyebab gangguan psikis. Faktor sosial terdapat dua yaitu keluarga dan sosial-budaya. Keluarga adalah faktor sosial paling utama yang memberikan pengaruh-pengaruh predisposional psikotis kepada anak-anak dan orang muda. ${ }^{30}$ Pada dasarnya keluarga memiliki beberapa fungsi keluarga yang harus dijalankan. Menurut Berns dalam Lestari menyebutkan ada 5 (lima) fungsi keluarga antara lain fungsi reproduksi, sosialisasi/edukasi, penugasan peran sosial, dukungan ekonomi dan dukungan emosi/ pemeliharaan. Fungsi keluarga yang dapat terimplementasikan dengan baik anak dapat berkembang secara fisik, emosi, spiritual dan sosial yang baik pula. ${ }^{31}$ Akan tetapi ada

\footnotetext{
${ }^{28}$ Kartini Kartono, Patologi..., h.32

${ }^{29}$ Kartini Kartono, Patologi..., h.33

${ }^{30}$ Kartini Kartono, Patologi..., h.34

${ }^{31}$ Sri Lestari, Psikologi Keluarga: Penanaman Nilai
} 
keluarga yang tidak dapat menjalankan fungsi keluarga sehingga anak menjadi psikopatis, tidak pernah merasa aman dan pasti. Mereka merasa tidak diterima dan selalu merasa terasingkan. Hal itu dapat menghancurkan harga-diri anak, dan memberikan basis bagi pembentukan sikap-sikap paranoid dan psikopatik. ${ }^{32}$ Menurut Kartini Kartono, tidak berjalannya fungsi keluarga sebagai fungsi pendidik dan sosial akan membentuk sikapsikap paranoid dan psikopatik pada anak. Keluarga yang tidak mampu berfungsi sebagai pendidik mengakibatkan anak tidak bisa menjadi dewasa secara psikis, dan tidak dapat mandiri dalam kedewasaannya.

Yusuf dalam Baihaqi menjelaskan bahwa terdapat beberapa faktor yang dapat mengakibatkan perubahan kepribadian seseorang, antara lain: ${ }^{33} 1$ ) faktor fisik, seperti gangguan otak karena sakit atau kecelakaan, kurang gizi, obat-obatan terlarang (NAPZA/ Narkoba); 2) faktor lingkungan sosial budaya, seperti berbagai krisis sosial, politik, ekonomi, dan keamanan yang menyebabkan masalah pribadi seperti stress atau depresi dan masalahmasalah sosial lainnya seperti pengangguran, premanisme dan kriminalitas; 3) faktor dari individu itu sendiri, seperti tekanan emosional seperti frustasi yang berkepanjangan dan identifikasi atau imitasi terhadap orang lain yang berkepribadian menyimpang.

\section{Kekerasan Dalam Rumah Tangga Sebagai Perilaku Menyimpang}

Penyimpangan oleh James dalam Kamanto didefinisikan sebagai perilaku yang oleh sejumlah orang dianggap sebagai hal yang tercela dan diluar batas toleransi. Maksudnya perilaku tersebut tidak sesuai dengan harapan masyarakat. ${ }^{34}$ Menurut Elly dan Usman antara lain: Pertama, adanya gangguan mental (sikap

dan Penanganan Konflik dalam Keluarga (Jakarta: Kencana Prenada Media Group, 2012), h. 22

${ }^{32}$ Kartini Kartono, Patologi..., h. 35

${ }^{33}$ MIF Baihaqi, dkk, Psikiatri..., h. 133

${ }^{34}$ Kamanto Sunarto, Pengantar Sosiologi (Jakarta: Lembaga Penerbit Fakultas Ekonomi Universitas Indonesia, 2004), h. 176 mental yang tidak sehat) seperti depresi, deprivasi social, psikopati, antisocial dan lain sebagainya. Kedua, Ketidak harmonisan dalam keluarga (mengalami broken home). Ketiga, Pelampiasan rasa kecewa. Keempat, Dorongan Ekonomi. Kelima, pengaruh lingkungan dan media massa. Keenam, keinginan untuk dipuji. Ketujuh, proses belajar yang menyimpang. Kedelapan, ketidaksanggupan menyerap norma, dan Kesembilan, proses sosialisasi nilai-nilai subkultur menyimpang.

Dilihat dari teori perilaku menyimpang, maka tindak kekerasan dalam rumah tangga dapat dikategorikan sebagai penyimpangan. Karena kekerasan dalam rumah tangga adalah suatu perbuatan yang tercela dan tidak dapat ditoleransi, mengingat dampak dari kekerasan dalam rumah tangga seringkali mengancam jiwa seseorang bahkan tidak sedikit yang menyebabkan kematian. Sedangkan faktor penyebabnya dalam pengamatan Dadang Hawari disebabkan karena adanya gangguan mental/psikis pelaku.

\section{Tinjauan Maqa'shid al-Syari'ah dan Sadz al-Dzariah terhadap Pemeriksaan Psikis Pra-Nikah}

Imam al-Syatibi dalam kitab al-Muwafaqat manyatakan bahwa maqa'shid al-syari'ah adalah tujuan hukum yang diturunkan oleh Allah SWT. Lebih lanjut, al-Syatibi menyatakan bahwa tujuan tersebut tidak lain kecuali menciptakan kemaslahatan bagi manusia di dunia dan akhirat. ${ }^{35}$ Menurut al-Syatibi, kemaslahatan itu dapat diwujudkan melalui lima unsur pokok yaitu agama, jiwa, keturunan, akal dan harta. Dalam usaha mewujudkan dan memelihara lima unsur pokok itu, ia membagi tujuan syari'ah menjadi tiga tingkatan; Pertama, maqa<shid al-daruriyat yang dimaksudkan untuk memelihara lima unsur pokok dalam kehidupan manusia (agama, jiwa, keturunan, akal dan harta). Kedua, maqa $<$ shid al-hajiyat yang dimaksudkan untuk menghilangkan kesulitan atau menjadikan pemeliharaan terhadap

${ }^{35}$ Asafri Jaya Bakri, Konsep Maqashid Syari'ah Menurut Al-Syatibi (Jakarta: Raja Grafindo Persada, 1996), h. 64 
lima unsur pokok menjadi lebih baik. Ketiga, maqa<shid al-tahsiniyat, yang dimaksudkan agar manusia dapat melakukan yang terbaik untuk menyempurnakan pemeliharaan lima unsur pokok. ${ }^{36}$

Kekerasan dalam rumah tangga seringkali menciderai korbannya baik secara fisik maupun secara psikis. Menurut Mufidah, ada beberapa dampak dari kekerasan dalam rumah tangga, antara lain: ${ }^{37}(1)$ Dampak fisik seperti lukaluka, memar, lecet, gigi rompal, patah tulang, kehamilan, aborsi (keguguran), penyakit menular (HIV/AIDS, hingga kematian. Dampak pertama ini terutama yang mengakibatkan kematian sangat bertentangan dengan Islam, karena Islam melindungi hak hidup seseorang. Sebagaimana firman Allah SWT dalam Q.S. Al-Israa': 33 yang artinya: Dan janganlah kamu membunuh jiwa yang diharamkan Allah (membunuhnya), melainkan dengan suatu (alasan) yang benar; (2) Dampak psikis seperti sering menangis, tidak bisa bekerja, mudah lelah, mudah marah, trauma, depresi dan lain sebagainya. Dampak kedua ini bertentangan dengan perlindungan Islam terhadapjiwa dan akal, karena seseorang yang depresi dapat membahayakan jiwanya karena tanpa sadar melukai dirinya sendiri dan dapat mengancam keselamatan nyawanya apabila depresi korban tersebut akut, dan tidak jarang berusaha bunuh diri. Selain itu seseorang yang mengalami depresi akalnya juga terganggu sehingga tidak dapat digunakan untuk berfikir positif; (3) Dampak seksual seperti kerusakan organ reproduksi, tidak dapat hamil, pendarahan, kemungkinan keguguran, menopause dan lain sebagainya.; (4) Dampak ekonomi bisa berbentuk kehilangan penghasilan, kehilangan tempat tinggal, harus menanggung biaya perawatan medic akibat kekerasan, kehilangan waktu produktif karena tidak mampu bekerja, dan harus menanggung nafkah keluarga dalam kasus penelantara.

Menurut Rusmil dalam Huraerah

\footnotetext{
${ }^{36}$ Asafri Jaya Bakri, Konsep..., h. 72

${ }^{37}$ Mufidah CH, Psikologi Keluarga Islam Berwawasan Gender (Malang: UIN Malang Press, 2008), 276-277
}

mengemukakan, bahwa anak-anak yang menderita kekerasan, eksploitasi, pelecehan, dan penelantaran akan berdampak seperti berusia lebih pendek, kesehatan fisik dan mental yang buruk, masalah pendidikan (termasuk dropt-out dari sekolah), kemampuan yang terbatas sebagai orangtua kelak, dan menjadi gelandangan. ${ }^{38}$ Suharto menegaskan bahwasannya kekerasan dalam rumah tangga dengan korban seorang anak, akan berdampak sangat serius dan kekerasan tersebut dapat menyebabkan hak-hak yang paling mendasar dalam kehidupan anak. Suharto menambahkan, bahwasannya seorang anak yang menjadi korban kekerasan akan mengalami luka baik fisik maupun psikis, seperti cacat tubuh permanen, kegagalan belajar, gangguan emosional bahkan dapat menjurus pada gangguan kepribadian, konsep diri yang buruk dan ketidakmampuan untuk mempercayai atau mencintai orang lain, agresif dan kadang-kadang melakukan tindak criminal, menjadi penganiaya ketika dewasa, menggunakan obat-obatan atau alcohol, dan kematian.

Richard J.Gelles dalam Huraerah juga menguatkan pendapat di atas, bahwasannya dalam beberapa kasus kekerasan terhadap anak dapat mengakibatkan gangguan-gangguan kejiwaan (psychiatric disorders) seperti: depresi, kecemasan berlebihan, atau gangguan identitas disosiatif, dan juga bertambahnya risiko bunuh diri. ${ }^{39}$ Selain dari dampak tersebut diatas yang lebih bersifat inmateri, kekerasan dalam rumah tangga juga berdampak pada rusaknya harta dalam rumah tangga. Disimpulkan, bahwsannya kekerasan dalam rumah tangga tidak hanya mengancam jiwa, akal, keturunan yang baik, tapi juga terhadap harta benda yang dirusak akibat percekcokan yang berujung kekerasan. Dilihat dari dampaknya, kekerasan dalam rumah tangga bertentangan dengan konsep maqa<shid al-syari'ah, karena pada prinsipnya Islam sangat menjunjung tinggi hak hidup, memelihara akal, nasab, harta yang termaktub

\footnotetext{
${ }^{38}$ Abu Huraerah, Kekerasan Terhadap Anak (Bandung: Penerbit Nuansa Cendekia, 2012), h. 55

${ }^{39} \mathrm{Abu}$ Huraerah, Kekerasan...., h. 56
} 
dalam al-kulliyyat al-khams. Perlindungan terhadap lima hal ini dapat diperkuat salah satunya dengan melakukan pemeriksaan psikis pra-nikah. Karena faktor-faktor penyebab kekerasan dalam rumah tangga dapat dideteksi dan ditanggulangi sejak awal.

Sementara itu, setiap perbuatan yang secara sadar dilakukan oleh seseorang pasti mempunyai tujuan tertentu yang jelas, baik perbuatan yang akan dilakukan itu baik atau buruk, membawa manfaat atau menimbulkan mudharat. Sebelum sampai pada pelaksanaan perbuatan yang dituju itu ada serentetan perbuatan yang mendahuluinya. Sebelum melakukan perbuatan yang dituju tersebut baik yang menimbulkan manfaat maupun mudharat dalam perbuatan tersebut pasti terdapat perantara (pendahuluan) yang oleh ahli ushul disebut dengan al-dzari' ah (الذرعة). ${ }^{40}$

Menurut Ibnu Qayyim al-Jauziyyah dan Imam al-Qarafi, mengatakan bahwa al-dzari'ah itu adakalanya yang dilarang yang biasanya disebut dengan sad al-dzari'ah (menutup segala aspek apabila hal itu adalah sarana menuju sebuah mafsadah atau hal-hal yang dilarang), dan adakalanya dianjurkan bahkan diwajibkan yang disebut fath al-dzari'ah (membuka segala aspek apabila hal tersebut adalah sarana untuk mendatangkan maslahah. ${ }^{41}$ Menurut Dadang Hawari gangguan psikologis pada diri seseorang menjadi salah satu faktor pemicu kekerasan dalam rumah tangga ${ }^{42}$. Gangguan psikis seseorang merupakan al-dzari'ah dari tindakan kekerasan dalam rumah tangga yang dilarang oleh ajaran Islam. Oleh karena itu sangatlah tepat ketika diadakan langkah preventif berupa pemeriksaan psikis pranikah sebagaimana yang telah dilakukan oleh beberapa Negara Islam seperti Iraq, Yordan, Lebanon, Marocco, Tunisia dan Yaman ${ }^{43}$ sehingga

\footnotetext{
${ }^{40}$ Amir Syarifuddin, Ushul Figh Juz-2 (Jakarta: Kencana, 2009), h. 424

${ }^{41}$ Rachmat Syafe'i, Ilmu Ushul Fiqih (Bandung: Pustaka Setia, 1998), h. 139

${ }^{42}$ Dadang Hawari, Penyiksaan Fisik...., 89

${ }^{43}$ Tahir Mahmood, Personal Law in Islamic Countries (History, Text and Comparative Analysis) (New Delhi: Academy of Law and Religion, 1987), h. 271
}

dengan pemeriksaan tersebut dapat dideteksi tingkat tempramen seseorang sehingga dapat dicegah dan diminimalisir. Pemeriksaan psikis pranikah yang bertujuan untuk menekan angka kekerasan dalam rumah tangga selaras dengan konsep maqa<shid al-syari<'ah yaitu menciptakan kemaslahatan bagi umat manusia, karena pemeriksaan psikis pranikah tanpa disadari bertujuan melindungi 4 (empat) dari 5 (lima) hal pokok yang dilindungi oleh Islam yaitu jiwa, harta, keturunan dan akal yang seringkali hilang karena tindak kekerasan dalam rumah tangga.

\section{Metode Penelitian}

Penelitian ini merupakan penelitian lapangan (field reasearch), ${ }^{44}$ dengan menggunakan pendekatan kualitatif. ${ }^{45}$ Penelitian ini dilakukan di Kota Malang dengan pertimbangan jumlah perkara perceraian karena alasan KDRT yang putus Pengadilan Agama Kota Malang meningkat setiap tahun. Selain itu di Kota Malang terdapat berbagai lembaga yang melakukan pendampingan korban kekerasan dalam rumah tangga. Data penelitian berupa data primer yaitu, hasil wawancara dari kepada KUA se-Kota Malang dan beberapa orang psikolog yang digali dengan teknik wawancara mendalam (depth interview). ${ }^{46}$ Dengan data sekunder berupa data statistik perceraian di Pengadilan Agama Kota Malan, buku, jurnal, laporan, peraturan dan catatan terkait KDRT. Alanisis data dilakukan melalui tiga tahapan yaitu reduksi data, penyajian data, dan menarik kesimpulan. ${ }^{4}$ Pengecekan keabsahan data menggunakan triangulasi sumber yang membandingkan hasil wawancara dengan data sekunder, dan triangulasi teori. ${ }^{48}$

${ }^{44}$ Lexy J. Moeleong, Metodologi Penelitian Kualitatif (Bandung: PT Rosda Karya, 2006), h. 26.

${ }^{45}$ Lexy J. Moeleong, Metodologi..., h.3

${ }^{46} \mathrm{M}$. Djunaidi Ghony dan Fauzan Almanshur, Metodologi Penelitian Kualitatif (Jogjakarta: Ar-Ruzz Media, 2012), h. 175

${ }^{47}$ Emzir, Metodologi Penelitian Kualitatif Analisis Data (Jakarta:Rajawali Press, 2010), h. 129-135

${ }^{48}$ Lexy J. Moleong, Metodologi..., 326 


\section{Hasil dan Pembahasan}

\section{Pandangan Kepala KUA dan Psikolog di Kota Malang tentang Pemeriksaan Psikis Pra-nikah}

Penelitian Tahir Mahmood menunjukkan bahwa di beberapa negara muslim seperti Iraq, Yordan, Lebanon, Marocco, Tunisia dan Yaman melakukan pemeriksaan psikis (mental capacity) terhadap calon pengantin yang diduga mengalami gangguan mental atas persetujuan pasangannya. Pemeriksaan ini merupakan upaya preventif bagi pasangan suami-istri agar memiliki kesiapan psikis sehingga tidak terjadi perceraian. ${ }^{49}$ Pemeriksaan psikis pra-nikah adalah serangkaian pemeriksaan kesehatan psikologis bagi calon pengantin oleh psikolog menggunakan alat tes MMPI (Minnesota Multiphasic Personality Inventory). Melalui tes ini berbagai gangguan kejiwaan yang dapat mengakibatkan rusaknya hubungan suami-istri dan pemicu kekerasan dalam rumah tangga dapat terdeteksi. ${ }^{50}$

Berdasarkan hasil wawancara diketahui bahwa seluruh informan, yaitu Kepala KUA dan Psikolog di Kota Malang setuju dilakukan pemeriksaan psikis pra-nikah terhadap calon pasangan. Karena tidak sedikit suami istri yang bercerai akibat emosi yang tidak terkontrol hingga muncul kekerasan dalam rumah tangga. Argumen ini didukung oleh penelitian Dadang Hawari menunjukkan bahwa salah satu pemicu terjadinya kekerasan dalam rumah tangga saat ini adalah gangguan jiwa atau kepribadian pasangan yang tidak diketahui sejak awal atau sebelum melangsungkan perkawinan. ${ }^{51}$

Meskipun demikian, pelaksanan harus didahului terbentuknya peraturan perundangundangan yang mengatur tentang pemeriksaan psikis pranikah. Sebagai penyelengara urusan perkawinan umat Islam, KUA tidak berwenang

\footnotetext{
${ }^{49}$ Tahir Mahmood, Personal Law..., h. 271.

${ }^{50}$ Dadang Hawari, Psikometri Alat Ukur (Skala) Kesehatan Jiwa (Jakarta: Balai Penerbit Fakultas Kedokteran Universitas Indonesia, 2009), h. 7

${ }^{51}$ Dadang Hawari, Penyiksaan Fisik dan Mental dalam Rumah Tangga (Domestic Violence) (Jakarta: Balai Penerbit Fakultas Kedokteran Universitas Indonesia, 2009), h. 89
}

melaksanakan pemeriksaan psikis jika belum ada aturannya. Hal ini merupakan konsekuensi dari dianutnya konsep negara hukum di Indonesia. ${ }^{52}$ Salah satu cirinya yaitu berlakunya asas legalitas yang menyatakan bahwa segala tindakan pemerintah, termasuk KUA harus didasarkan atas peraturan perundang-undangan yang sah dan tertulis. ${ }^{53}$ Beberapa peraturan perundang-undangan di Indonesia sebenarnya memberikan motivasi kepada pemerintah untuk mengatur pemeriksaan psikis pra-nikah secara formal. Misalnya dalam Pasal 9 UndangUndang RI Nomor 39 tahun 1999 tentang Hak Asasi Manusia menyatakan bahwa "setiap orang berhak untuk hidup, mempertahankan hidup dan meningkatkan taraf kehidupannya. Setiap orang berhak hidup tenteram, aman, damai, bahagia, sejahtera lahir dan batin". Selain itu, dalam Pasal 11 Undang-Undang Nomor 23 Tahun 2004 tentang PKDRT disebutkan bahwa "pemerintah bertanggung jawab dalam upaya pencegahan kekerasan dalam rumah tangga". ${ }^{44}$ Penghapusan kekerasan dalam rumah tangga bisa dilakukan salah satunya dengan kebijakan pemeriksaan psikis pra-nikah. Sebagai indikasi bahwa hukum di Indonesia bersifat responsif. ${ }^{55}$

Selain itu, perlu dilakukan sosialisasi secara terus menerus kepada masyarakat, untuk mewujudkan kesadaran hukum. Sehingga berbagai peraturan tentang perkawinan menjadi efektif. ${ }^{56}$ Sosialisasi yang efektif dapat mencegah

\footnotetext{
${ }^{52}$ Juhaya S. Praja, Teori Hukum dan Aplikasinya (Bandung: Pustaka Setia, 2011), h. 140

${ }^{53}$ Bahder Johan Nasution, Negara Hukum dan Hak Asasi Manusia (Bandung: Mandar Maju, 2011), 21

${ }^{54}$ Undang-Undang Republik Indonesia No. 23 Tahun 2004 tentang Penghapusan Kekerasan Dalam Rumah Tangga (Jakarta: Sinar Grafika, 2007), h. 6

${ }^{55}$ Hukum Responsif merupakan hukum yang diimplementasikan sebagai fasilitator dari respon terhadap kebutuhan-kebutuhan dan aspirasi masyarakat. Hukum responsif bertujuan agar hukum lebih tanggap terhadap kebutuhan warga masyarakat, dan lebih efektif menangani konflik yang terjadi dalam kehidupan social masyarakat. Lihat Marwan Mas, Pengantar Ilmu Hukum (Bogor: Penerbit Ghalia Indonesia, 2011), h.118

${ }^{56}$ Achmad Ali, Menguak Teori Hukum (Legal Theory) dan Teori Peradilan (Judicial Prudence) termasuk Interpretasi Undang-Undang (Legis Prudence) (Jakarta: Kencana, 2012), h. 299
} 
timbulnya penilaian negatif dari masyarakat terhadap KUA. Selain untuk memahami fungsi, tujuan, pembiayaan, pendampingan pasca pemeriksaan psikis pra-nikah, sosialisasi diharapkan mampu menanggulangi munculnya stigma negatif yang dialamatkan kepada KUA. Untuk itu, stakeholder ${ }^{57}$ kunci dalam masyarakat, seperti kiai, ulama, tokoh adat, camat, lurah, hingga ketua RT harus dilibatkan. Keberadaannya dapat membantu memperlancar sosialisasi program-program pemerintah. Sehingga tidak ada anggapan bahwa pemeriksaan psikis pra-nikah akan menyebarkan aib seseorang. Pandangan para informan memiliki korelasi dengan argumen Seidman dan Astrid S. Susanto yang mengatakan bahwa hukum itu perlu dikomunikasikan dengan masyarakat dengan cara mensosialisasikan hukum itu sehingga masyarakat faham akan isi dari hukum beserta manfaat yang terkandung. ${ }^{58}$

Sebagai upaya pencegahan tindak kekerasan dalam rumah tangga, Kementerian Agama di seluruh Indonesia telah mencanangkan program kursus calon pengantin (Suscatin) sebagaimana diatur dalam PMA No. 11 Tahun 2007 tentang Suscatin. Melalui program ini calon pengantin diberikan bekal pengetahuan tentang rumah tangga, misalnya hak dan kewajiban suami-istri. Hanya saja, program ini minim peminat. Pasangan calon pengantin enggan mengikuti program dengan alasan tidak punya banyak waktu luang. Sebagai solusi persoalan ini, pihak KUA memberikan bimbingan terhadap pasangan calon pengantin pada saat mendaftarkan pernikahan di KUA. Meskipun diberikan dalam waktu yang relatif singkat, diharapkan program ini bisa memberikan bekal bagi pasangan calon pengantin sehingga memiliki kesiapan secara psikis.

${ }^{57}$ Stakeholder dapat diartikan sebagai segenap pihak yang terkait dengan isu dan permasalahan yang sedang diangkat. Stakeholder juga dapat didefinisikan sebagai pemangku kepentingan. Berdasarkan kekuatan, posisi penting, dan pengaruh stakeholder terhadap suatu issu stakeholder dapat diketegorikan kedalam beberapa kelompok yaitu stakeholder primer, sekunder dan stakeholder kunci . Pemangku Kepentingan, http:// id.wikipedia.org, diakses tanggal 15 Juli 2013

${ }^{58}$ Muslan Abdurrahman, Sosiologi dan Metode Penelitian Hukum (Malang: UMM Press, 2009), h. 39

\section{Pemeriksaan Psikis Pra-nikah Sebagai Upaya Preventif KDRT}

Undang-Undang No. 36 Tahun 2009 tentang Kesehatan memberikan pengertian sehat dengan keadaan sehat baik secara fisik mental spiritual maupun sosial yang memungkinkan setiap orang untuk hidup produktif secara sosial dan ekonomis. Berdasarkan pengertian di atas, fisik dan psikis merupakan kesatuan dalam eksistensi manusia, keduanya saling berhubungan. Keadaan fisik manusia mempengaruhi psikisnya, begitu pula sebaliknya. Penelitian yang dilakukan oleh Hall menunjukkan bahwa pasien yang mengidap penyakit fisik mengalami gangguan mental seperti depresi, gangguan kepribadian, atau sindrom.

Dalam perkawinan kesehatan fisik dan psikis mutlakdiperlukanuntukmewujudkan kehidupan yang harmonis. Sebelum melangsungkan pernikahan, calon pengantin diwajibkan memeriksakan kesehatannya sebagaimana diatur dalam Instruksi Depkes dan Depag No. 02 Tahun 1989 tentang suntik TT. Hanya saja, Instruksi ini hanya bertujuan mengetahui dan memberikan kekebalan tubuh. Tindakan ini belum cukup menggambarkan kesehatan pasangan calon pengantin. Sebagaimana amanat Undang-Undang Kesehatan, tidak hanya aspek fisik yang perlu diperhatikan melainkan juga aspek psikis seseorang. Hal ini didukung dengan fakta bahwa tidak sedikit rumah tangga yang gagal dan berujung pada perceraian, baik disebabkan karena ketidakharmonisan, pertengkaran yang tidak berujung, penelantaran ekonomi, hingga kekerasan dalam rumah tangga.

Berdasarkan gambaran di atas, para informan penelitian sependapat bahwa pemeriksaan psikis merupakan langkah yang tepat sebagai upaya preventif terhadap berbagai masalah rumah tangga. Kelainan dan gangguan psikologis calon pasangan, seperti emosi yang tidak stabil, sikap posesif, kecurigaan berlebihan, dapat terdeteksi dan dilakukan konseling secara berkala. Menurut Kartini Kartono gangguan 
psikis tidak begitu saja terjadi. ${ }^{59}$ Bahkan menurut Dadang Hawari, gangguan psikis dapat dideteksi mulai remaja. Data penelitian ini menunjukkan bahwa gangguan psikis yang terjadi di Kota Malang sebagian besar terjadi karena faktor sosial-budaya seperti masalah ekonomi, masalah anak, masalah orang tua. Kapasitas mental yang tidak kuat cenderung akan menyelesaikan persoalan dengan jalan kekerasan. Oleh karena itu, pemeriksaan psikis pra-nikah selaras konsep maqa<shid al-syari<'ah yang bertujuan menciptakan kemaslahan bagi umat manusia di dunia dan akhirat yaitu melindungi agama, jiwa, akal, keturunan dan harta. Sebagaimana ungkapan al-Syatibi dalam al-muwafaqat:

$$
\text { المصالح البمتلبة شرعا والمفاسد المستدفعة انما تعتبرمن حيث تقام الحياة }
$$

Artinya: Kemaslahatan yang harus diwujudkan dan kemafsadatan yang harus dihapuskan menurut syara' harus diarahkan pada tegaknya kehidupan dunia akhirat"

Jika ditinjau dari teori sadd dzari' h $^{60}$ kekerasan dalam rumah tangga termasuk perbuatan yang dilarang oleh syara' dan perbuatan tersebut harus dicegah termasuk perantara yang dapat menjadi perantara terjadinya kekerasan. Salah satunya adalah gangguan psikis yang terjadi pada pasangan suami-istri.

\section{Kesimpulan}

Beberapa kesimpulan yang dapat ditarik dari penelitian ini sebagai berikut: Pertama, pemeriksaan psikis pra-nikah di Kota Malang belum dilaksanakan secara formal seperti halnya pemeriksaan kesehatan di Puskesmas Kecamatan. Sebagai gantinya, pihak KUA telah melaksanakan program kursus calon pengantin untuk mendeteksi gangguan psikis dari calon mempelai. Hanya saja, program ini tidak efektif karena tidak diimbangi dengan partisipasi aktif dari masyarakat khususnya calon pengantin. Sehingga program ini masih membutuhkan

\footnotetext{
${ }^{59}$ Kartini Kartono, Patologi ..., h. 27-34

${ }^{60}$ Forum Karya Ilmiah, Kilas Balik Teoritis Fiqh Islam (Kediri: Madrasah Hidayatul Mubtadi-ien, 2004), h. 300
}

sosialisasi secara intensif serta keterlibatan stakeholder agar masyarakat menyadari urgensi pemeriksaan psikis pra-nikah melalui pogram suscatin. Selain itu, pelaksanannya harus mendapat legitimasi peraturan perundangundangan sebagai konsekuansi dari dianutnya asas legalitas dalam negara hukum dan tradisi hukum tertulis dalam civil law system.

Kedua, seluruh informan sepakat bahwa pemeriksaan psikis pra-nikah merupakan tawaran solusi atas berbagai kasus kekerasan dalam rumah tangga akibat gangguan kejiwaan anggota keluarga. Sebagai alat deteksi dini gangguan kejiwaan pasangan suami-istri, pemeriksaan psikis pranikah tidak menciderai hak asasi manusia apabila dilakukan sesuai prosedur. Pemeriksaan psikis pra-nikah relevan dengan konsep sâd dzari'ah dan konsep maquashid syari'ah karena program ini mampu mencegah gangguan psikologis yang menjadi perantara terjadinya kekerasan dalam rumah tangga. Sehingga keselamatan terhadap jiwa dalam konteks rumah tangga menjadi terwujud.

\section{Saran}

Bagi Pemerintah karena telah terbukti bahwasannya saat ini factor penyebab terjadinya kekerasan dalam rumah tangga tidak hanya ekonomi melainkan adanya gangguan psikis pada pasangan dan hanya dapat diketahui dengan pemeriksaan psikis, maka pemerintah segera membentuk peraturan sebagai dasar pijakan pihak KUA untuk melaksanakan program pemeriksaan psikis pranikah.

Bagi Pihak KUA agar suscatin dapat terlaksana dengan baik, maka harus ada sosialisasi yang lebih serius sehingga masyarakat faham akan manfaat dibalik diwajibkannya kursus calon pengantin yang juga menjadi salah satu pencegah kekerasan dalam rumah tangga melalui pemahaman pasangan calon pengantin sehingga nantinya pemeriksaan psikis yang akan menjadi bagian dari suscatin juga dapat terlaksana dengan baik.

Bagi Masyarakat agar mentaati apa yang diwajibkan di KUA karena sesungguhnya pemerintah mewajibkan pasti memiliki manfaat 
bagi masyarakat. Karena penelitian ini sebatas mengungkap bagaimana pandangan Kepala KUA dan Psikolog terhadap pemeriksaan psikis pranikah dan urgensinya, maka sebagi penyempurna dari penelitian ini, diharapkan

\section{DAFTAR PUSTAKA}

Abdurrahman, Muslan. Sosiologi dan Metode Penelitian Hukum. Malang: UMM Press. 2009

Ali, Achmad. Menguak Teori Hukum (Legal Theory) dan Teori Peradilan (Judicial Prudence) termasuk interpretasi undang-undang (Legis Prudence). Jakarta: Kencana. 2012.

AM, Ikrom. Persinggungan Antara Psikopatologi dan Kesehatan Mental Sufistik. Semarang: Walisongo Press. 2009

Ardani, Tristiadi Ardi. Psikiatri Islam. Malang: UIN-Malang Press. 2008

Baihaqi, MIF dkk. Psikiatri Konsep Dasar dan Gangguan-Gangguan. Bandung: Refika Aditama. 2007

Bakri, Asafri Jaya. Konsep Maqashid Syari'ah Menurut Al-Syatibi. Jakarta: Raja Grafindo Persada. 1996

Emzir. Metodologi Penelitian Kualitatif Analisis Data. Jakarta:Rajawali Press, 2010

Forum Karya Ilmiah, Kilas Balik Teoritis Figh Islam. Kediri: Madrasah Hidayatul Mubtadiien. 2004

Ghony, M. Djunaidi dan Fauzan Almanshur. Metodologi Penelitian Kualitatif. Jogjakarta: Ar-Ruzz Media. 2012

Hawari, Dadang Penyiksaan Fisik dan Mental dalam Rumah Tangga (Domestic Violence). Jakarta:Balai Penerbit Fakultas Kedokteran Universitas Indonesia, 2009 Psikometri Alat Ukur (Skala) Kesehatan Jiwa. Jakarta: Balai Penerbit Fakultas KedokteranUniversitas Indonesia. 2009

Huraerah, Abu. Kekerasan Terhadap Anak. Bandung: Penerbit Nuansa Cendekia, 2012

Instruksi Depag dan Depkes No. 1 tahun 1989 tentang Pemeriksaan Kesehatan Pranikah. ada penelitian lanjutan yang meneliti tentang pandangan masyarakat dan pemerintah tentang pemeriksaan psikis pranikah dan kesemuanya itu akan menjadikan penelitian yang peneliti teliti ini sempurna dan dapat direalisasikan.

Kartono, Kartini. Patologi Sosial 3: GangguanGangguan Kejizwaan. Jakarta:PT RajaGrafindo Persada. 2012

Kementerian Negara Pemberdayaan Perempuan Republik Indonesia dan Badan Pemberdayaan Perempuan dan Keluarga Berencana Provinsi Jawa Timur, Statistik dan Analisis: Gender, Anak, dan Perempuan Provinsi Jawa Timur Tahun 2009. Surabaya: NKKBN, 2009

Komnas Perempuan. Kegentingan Kekerasan Seksual Lemahnya Upaya Penanganan Negara Catatan Kekerasan Terhadap Perempuan Tahun 2013.Jakarta: Komnas Perempuan. 2013

Komnas Perempuan. Korban Berjuang, Publik Bertindak: Mendobrak Stagnansi Sistem Hukum Catatan KTP Tahun 2012. Jakarta: Komnas Perempuan. 2013

Komnas Perempuan. Stagnansi Sistem Hukum: Menggantung Asa Perempuan Korban Catatan KTP Tahun 2011. Jakarta: Komnas Perempuan. 2012

Komnas Perempuan. Teror dan Kekerasan Terhadap Perempuan: Hilangnya Kendali Negara Catatan KTP Tahun 2010. Jakarta: Komnas Perempuan. 2011

Lestari, Sri. Psikologi Keluarga: Penanaman Nilai dan Penanganan Konflik dalam Keluarga. Jakarta: Kencana Prenada Media Group. 2012

Mahmood, Tahir. Personal Law in Islamic Countries (History, Text and Comparative Analysis). New Delhi: Academy of Law and Religion. 1987

Maramis, Willy F. dan Albert A. Maramis. Catatan Ilmu Kedokteran Jiwa. Surabaya: Airlangga University Press. 2009

Mas, Marwan. Pengantar Ilmu Hukum. Bogor: Penerbit Ghalia Indonesia. 2011 
30 | de Jure, Jurnal Syariah dan Hukum, Volume 7 Nomor 1, Juni 2015, hlm. 18-30

Missa, Lamber. Studi Kriminologi Penyelesaian Kekerasan Dalam Rumah Tangga Di Wilayah Kota Kupang Propinsi Nusa Tenggara Timur. Semarang: Fakultas Hukum Univ. Diponegoro. 2010

Moeleong, Lexy J. Metodologi Penelitian Kualitatif. Bandung: PT Rosda Karya, 2006

Mufidah CH. Psikologi Keluarga Islam Berwawasan Gender. Malang: UIN Malang Press, 2008

Murtadho, Ali. Konseling Perkawinan Perspektif Agama-Agama. Semarang: Walisongo Press. 2009

Nasution, Bahder Johan. Negara Hukum dan Hak Asasi Manusia. Bandung: Mandar Maju. 2011

Pemangku Kepentingan, http://id.wikipedia.org, diakses tanggal 15 Juli 2013

Penyebab Perceraian tahun 2009-2012. www. pa-malangkota.go.id, diakses tanggal 20 Januari 2013.

Praja, Juhaya S. Teori Hukum dan Aplikasinya. Bandung: Pustaka Setia. 2011

Soeroso, Moerti Hidayati. Kekerasan dalam Rumah Tangga dalam PerspektifYuridis-Viktimologis. Jakarta: Sinar Grafika. 2010

Sunarto, Kamanto. Pengantar Sosiologi. Jakarta: Lembaga Penerbit Fakultas Ekonomi Universitas Indonesia. 2004

Syafe'i, Rachmat. Ilmu Ushul Fiqih. Bandung: Pustaka Setia. 1998

Syarifuddin, Amir. Ushul Figh Juz-2. Jakarta: Kencana. 2009

Undang-Undang Nomor 36 Tahun 2009 tentang Kesehatan LN. Tahun 2009 No, 144

Undang-Undang Republik Indonesia No. 23 Tahun 2004 tentang Penghapusan Kekerasan Dalam Rumah Tangga. Jakarta: Sinar Grafika, 2007 